Sains Malaysiana 49(9)(2020): 2035-2042

http://dx.doi.org/10.17576/jsm-2020-4909-01

\title{
Cultivation of Chlorella vulgaris in Anaerobically Digested Dairy Manure Wastewater (ADDMW) for Protein and Chlorophyll Production
}

(Pengkulturan Chlorella vulgaris dalam Air Buangan Sapi Cernaan Anaerobik (ADDMW) bagi Penghasilan Protein dan Klorofil)

TAufik TAufikurahman*, Muhammad Arief Ardiansyah, Novi Tri AstutiningSiH \& Eko Agus SuYonO

\section{ABSTRACT}

Chlorella vulgaris is a eukaryotic, unicellular green microalgae that can be harvested as protein source since it can contain protein up to $50 \%$ of its dry weight. However, its cultivation is costly due to the price of its growth medium. In this research we used bioslurry or known as anaerobically digested dairy manure wastewater (ADDMW) as growth medium for C. vulgaris, since dairy manure is known to contain high nitrogen and phosphorus and its availability relatively abundant in rural areas. The cultivation of $\mathrm{C}$. vulgaris in the ADDMW medium was conducted in lab-scale (19 L) photobioreactors. After 14 days the culture was able to produce chlorophyll content of $34.62 \mu \mathrm{g} / \mathrm{mL}$, and after 28 days was able to produce protein up to 35\% dry weight. Moreover, C. vulgaris was also able to reduce PO4-P, NH4-N and NO3-N levels in ADDMW by 45.95, 78.24 and 17.38\%, respectively.

Keywords: ADDMW; Chlorella vulgaris; chlorophyll; phytoremediation; protein

ABSTRAK

Chlorella vulgaris adalah mikroalgae bersel tunggal yang memiliki kandungan protein sehingga 50\% berat keringnya. Namun kos pengkulturan C. vulgaris adalah tinggi kerana medium pengkulturannya yang mahal. Dalam kajian ini, kami menggunakan air buangan sapi cernaan anaerobik daripada proses penghasilan biogas. Pengkulturan C. vulgaris dalam medium air buangan sapi cernaan anaerobik (ADDMW) dalam fotobioreaktor (19 L) berskala makmal selama 14 hari dapat menghasilkan C. vulgaris dengan kandungan klorofil $34.62 \mu \mathrm{g} / \mathrm{mL}$ dan dalam 28 hari dapat menghasilkan C. vulgaris dengan kadar protein 35\% berat kering. Selain itu, kultur C. vulgaris dalam medium ADDMW dapat menurunkan kadar PO4-P, NH4-N dan NO3-N ADDMW masing-masing sebanyak 45.95, 78.24 dan 17.38\%.

Kata kunci: ADDMW; Chlorella vulgaris; fitopemulihan; klorofil; protein

\section{INTRODUCTION}

It is estimated that the current protein demand for 7.3 billion inhabitants of the world today is approximately 202 million tonnes globally. This figure could increase due to rapid population growth combined with rising incomes and urbanizing factors (Henchion et al. 2017). Therefore there is a need for searching alternative protein sources, and microalgal Chlorella vulgaris is one of them.

C. vulgaris is a eukaryotic, unicellular green microalga that can contain protein up to $50 \%$ of its dry weight (Liang et al. 2015). This microalgae is also an excellent producer of chlorophyll, an important product that is widely used in the food, cosmetics and pharmaceutical industries (Amin et al. 2018).

However, the cultivation of $C$. vulgaris requires high operational costs due to the price of the medium. As an alternative for an expensive growth medium, in this research, we cultivate $C$. vulgaris using anaerobically digested dairy manure wastewater (ADDMW) which is rich in nitrogen and phosphorus content (Taufikurahman \& Istiqomah 2019; Wang et al. 2010). We aimed to utilize bioslurry from the process of biogas production (ADDMW) as growth media to cultivate $C$. vulgaris which potentially can be extracted to produce protein and chlorophyll.

\section{MATERIALS AND METHODS}

PREPARATION OF MICROALGAE INOCULUM AND GROWTH MEDIUM

The inoculum of Chlorella vulgaris was obtained from Balai Besar Perikanan Budidaya Air Payau (BBPBAP) Jepara, Central Java. For preparation, C. vulgaris was cultivated using commercial Walne medium in $800 \mathrm{~mL}$ container, with a $20 \%$ initial concentration of $C$. vulgaris. The photoperiodism employed was $16 \mathrm{~h}$ of light: $8 \mathrm{~h}$ of dark using a timed white LED. An aeration pump with a power of 1 LPM was used for aeration. 
The dairy manure was obtained from the Faculty of Animal Husbandry, Padjadjaran University, West Java the ADDMW as a liquid effluent from a biodigester for biogas production. Sterilization was conducted using an autoclave at $121{ }^{\circ} \mathrm{C}$ for $15 \mathrm{~min}$. The remaining solid particles were removed before being utilized as a growth medium.

\section{CULTIVATION OF Chlorella vulgaris AND DEVELOPMENT OF GROWTH CURVE}

Culture of $C$. vulgaris was transferred to $19-\mathrm{L}$ photobioreactor after its concentration reached a minimum of 105 cells $/ \mathrm{mL}$. There were 3 variations on the growth medium we used in this study: The Walne medium which contain trace metal solution, vitamin solution and nutrient solution, with a concentration of $1 \mathrm{ppm}(\mathrm{v} / \mathrm{v})$, ADDMW, and a mix of both media.

A growth curve was made based on the cell number data to find out the growth phase of $C$. vulgaris. The cell number's measurement was carried using haemacytometer method with at four replications. A trinocular microscope integrated with NIS-Elements D software version 4.00 was also employed.

\section{EXTRACTION AND DETERMINATION OF PROTEIN AND CHLOROPHYLL CONTENT IN C. vulgaris}

Protein extraction was carried out using $3 \mathrm{~mL}$ of $0.5 \mathrm{~N}$ $\mathrm{NaOH}$ in two stages. Each stage lasts for $10 \mathrm{~min}$ at $80^{\circ} \mathrm{C}$. The supernatant obtained from this process was analyzed using the Bradford method to determine protein content of Chlorella. The wavelength used for the UV-VIS spectrophotometer was $595 \mathrm{~nm}$ with the BSA standard curve ranging from 0 to $1000 \mathrm{ppm}$. The determination of protein content was given in (1).

$$
\% \text { protein }=c \times \frac{V f}{1000} \times \frac{1}{D W}
$$

with $c$ is protein content in C. vulgaris (ppm); $V f$ is filtrate volume from 2 stages extraction $(\mathrm{mL})$; and $D W$ is dry weight (grams).

Chlorophyll extraction was carried out using the maceration method with acetone solvent and no light for $24 \mathrm{~h}$ (Simon \& Hellineell 1998). The analysis of chlorophyll content was held using a UV-VIS spectrophotometer with a wavelength of 645 and 663 $\mathrm{nm}$. Chlorophyll concentration was calculated using the following equations $(2,3,4)$ (Zheng et al. 2011).

$$
\begin{aligned}
& \text { Chl a }(\mu \mathrm{g} / \mathrm{mL}) \approx 11.8668 \mathrm{~A}_{663}-1.7858 \mathrm{~A}_{645} \\
& \text { Chl b }(\mu \mathrm{g} / \mathrm{mL}) \approx 18.9775 \mathrm{~A}_{645}-4.8950 \mathrm{~A}_{663} \\
& \text { Total chlorophyll }(\mu \mathrm{g} / \mathrm{mL})=\mathrm{Chl} \mathrm{a}+\mathrm{Chl} \mathrm{b}
\end{aligned}
$$

\section{DETERMINATION OF PO4-P, NH4-N, AND NO3-N LEVELS IN THE MEDIUM}

Prior to phosphorus and nitrogen analysis, the culture was centrifuged at $5000 \mathrm{rpm}$ for $10 \mathrm{~min}$. The determination of orthophosphate (PO4-P), ammonium (NH4-N), and nitrate (NO3-N) content were carried under a UV-VIS spectrophotometer with each specific reagent and specific wavelength.

PO4-P was analyzed using the Stannous Chloride $\left(\mathrm{SnCl}_{2}\right)$ method with a wavelength of $660 \mathrm{~nm}$. NH4-N was analyzed using Nessler with $420 \mathrm{~nm}$ of wavelength, while NO3-N was analyzed using APHA-4500- $\mathrm{NO}_{3}-\mathrm{B}-2012$ standard using $\mathrm{HCl}$ as a reagent with 220 and $275 \mathrm{~nm}$ as the wavelengths. The determination of removal efficiency was given in (5).

$$
\eta_{a}=\frac{\left(c_{a t}-c_{a 0}\right)}{c_{a t}} \times 100 \%
$$

with $\eta_{a}$ is the removal efficiency of substance a; $c_{a t}$ is the concentration of substance $a$ at time-t; and $c_{a 0}$ is the concentration of substance $a$ at time 0 .

\section{RESULTS AND DISCUSSION}

\section{PROTEIN PRODUCTION BY C. vulgaris IN WASTEWATER MEDIUM}

Cultivation of $C$. vulgaris for 14 and 28 days was carried out to see the comparison of product acquisition in the form of protein and chlorophyll in each medium. Cultivation in ADDMW medium for 28 days, has resulted

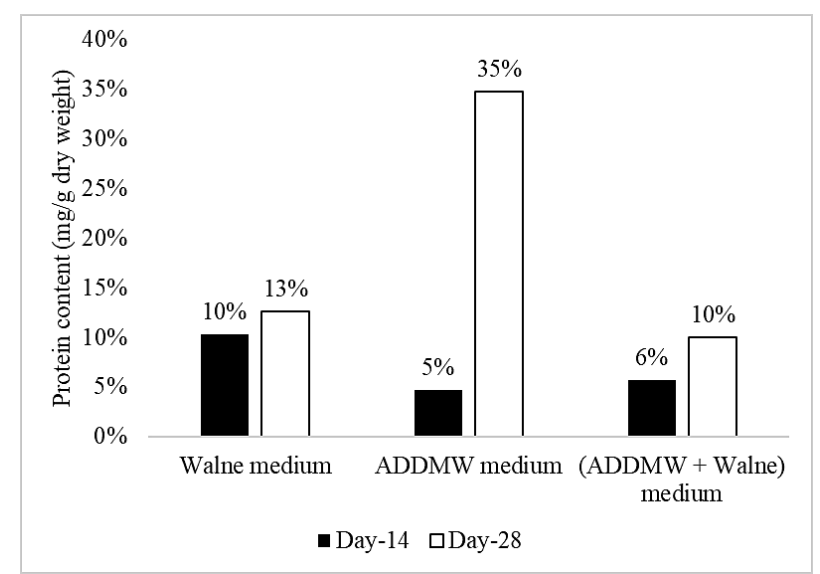

FIGURE 1. The comparison of protein content in C. vulgaris in various medium 
C. vulgaris to produce protein content $35 \%$ which is the highest compared to when grown in other media (Figure 1 ). This value is much higher than the protein content obtained from the other mediums that contain Walne. This indicated that the addition of Walne into the waste medium could not help to increase the level of protein in C. vulgaris significantly. However, the protein content obtained from this study was still relatively low compared to the previous studies, which was able to produce the protein levels in the range of 45 up to $60 \%$ of its dry weight (Chinnasamy et al. 2009; Hu et al. 2013; Jian-Ming et al. 2010).

The decreased levels of protein in microalgae may lead to a significant increase in carbohydrate and lipid levels, simultaneously. This may be caused by the interconnection of biosynthetic pathways that produce these three biochemical compounds due to energy allocations (Jian-Ming et al. 2010). Meanwhile, other research showed that cultivated Chlorella sp. in the ADDMW medium for 21 days was only able to produce lipids in the range of $9.0-13.7 \%$ of their dry weight (Wang et al. 2010).

Furthermore, the carbon fixation in the photosynthesis of microalgae is strongly influenced by the nitrogen and phosphorus composition of the substrate medium. It will tend to produce carbohydrates rather than protein if the culture medium has a limited nitrogen content (Hena et al. 2015), which can be represented by the N/P ratio values below 5 (Goncalves et al. 2017). Since the estimated N/P ratio in all mediums during the cultivation period was recorded below than 5 (Table 1 ), the cultivation was operated in nitrogen-limiting condition.

TABLE 1. Estimated N/P ratio during cultivation in all medium variations

\begin{tabular}{cccc}
\hline \multirow{2}{*}{ Day } & \multicolumn{3}{c}{ Estimated N/P ratio in the medium } \\
\cline { 2 - 4 } & Walne & ADDMW & ADDMW + Walne \\
\hline 0 & 0.00 & 0.98 & 0.54 \\
4 & 0.53 & 3.14 & 1.43 \\
8 & 0.67 & 3.33 & 0.65 \\
12 & 1.44 & 2.27 & 1.21 \\
14 & 1.92 & 1.30 & 0.41 \\
\hline
\end{tabular}

CHLOROPHYLL PRODUCTION BY C. vulgaris IN WASTEWATER MEDIUM

After 14 days cultivation, chlorophyll content in $C$. vulgaris grown in ADDMW was slightly higher than chlorophyll content in C. vulgaris grown in Walne medium (Figure 2). After 28 days however chlorophyll content of $C$. vulgaris grown in ADDMW reduced significantly, while chlorophyll content in C. vulgaris grown in Walne medium was relatively still the same as at 14 days. The highest total chlorophyll content in this study was depicted at $65.39 \mu \mathrm{g} / \mathrm{mL}$, which was obtained from the Walne medium after 28 days. Chl-a content in C. vulgaris after 14 days with a concentration of $34.62 \mu \mathrm{g} / \mathrm{mL}$ was about 3 times higher than the $C h l$-a value obtained by the Zehnder medium (Seyfabadi et al. 2011), but lower when compared to the ones obtained from a synthetic waste medium, which was able to reach up to $60 \mu \mathrm{g} / \mathrm{mL}$ ( $\mathrm{Zhu}$ et al. 2018).

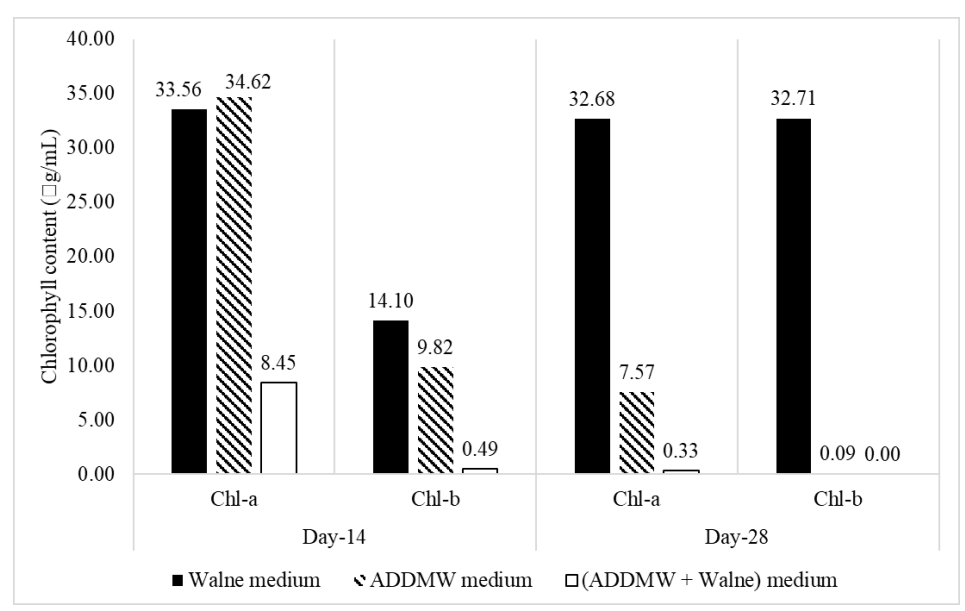

FIGURE 2. The comparison of Chl-a and Chl-b content in $C$. vulgaris cultivated in various medium 
The differences in Chl-a value among the studies were probably caused by differences in intensity, type, and a regime of light provided. The difference could also occur because of different nitrogen composition in the medium, which affect the synthesis process of the chlorophyll (Safafar et al. 2016).

Furthermore, the adequate levels of chlorophyll found in the ADDMW medium suggest the potential of this medium to produce chlorophyll as a by-product of the phytoremediation process. Chlorophyll production could be carried out before the lipid extraction process to produce an efficient and profitable process (Zheng et al. 2011).

GROWTH KINETICS OF C. vulgaris IN VARIOUS MEDIUM The growth curves based on cell count data showed that C. vulgaris successfully entered the exponential growth phase starting on the 12th day of cultivation (Figure 3). The ADDMW medium can generate the largest number of $C$. vulgaris cells up to $2.73 \times 10^{6}$ cells $/ \mathrm{mL}$, followed by the Walne medium with $1.69 \times 10^{6}$ cells $/ \mathrm{mL}$, and the ADDMW + Walne medium which presents the fewest number of cells with $3.03 \times 10^{5}$ cells $/ \mathrm{mL}$.

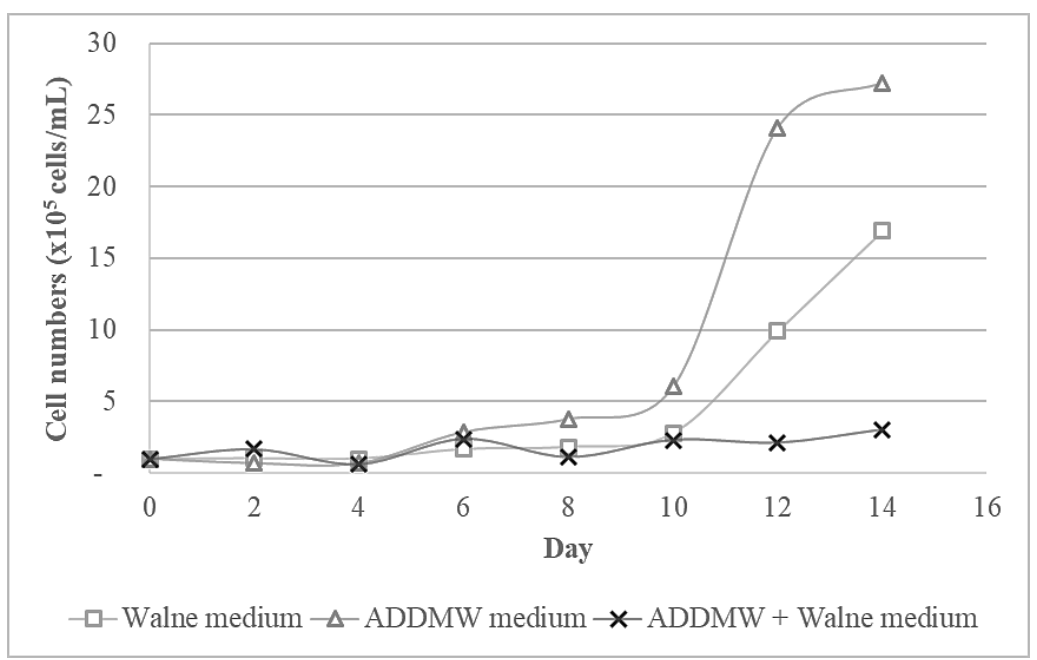

FIGURE 3. The growth curve of $C$. vulgaris on various medium based on cell count data using haemacytometer

The highest growth kinetics of $C$. vulgaris on the ADDMW medium is also reflected by the higher specific growth rate $(\mu)$ values and shorter doubling time $(d t)$ (Table 2). The $\mu$ value of $C$. vulgaris cultivated on the ADDMW medium was 0.693 days $^{-1}, 53 \%$ higher than the Walne medium, and 97\% higher than the ADDMW + Walne medium. This value is also higher than the $\mu$ value from other studies which reached $0.409 \mathrm{day}^{-1}$ with similar operating conditions (Wang et al. 2010). However, the value is lower than the one obtained at optimal operating conditions on a smaller scale which reached 1.00 days $^{-1}$ (Ji et al. 2014). Therefore, specific growth rate values are the best way to explain the ability of a species in adapting to its environmental conditions (Hena et al. 2015). Thus, the low value of specific growth rates in the ADDMW + Walne medium indicates the difficulty of $C$. vulgaris adaptation to that medium.

TABLE 2. Comparison of specific growth rate $(\mu)$ and doubling time $(d t)$ from $C$. vulgaris cultivated in various medium

\begin{tabular}{|c|c|c|}
\hline Medium & $\mu\left(\right.$ day $\left.^{-1}\right)$ & $d t$ (day) \\
\hline Walne & 0.452 & 1.53 \\
\hline ADDMW & 0.693 & 1.00 \\
\hline ADDMW + Walne & 0.352 & 1.97 \\
\hline
\end{tabular}


This phenomenon can also be described using the $\mathrm{N} / \mathrm{P}$ ratio. It is the ratio between the total inorganic nitrogen and the total inorganic phosphate available in the microalgae culture medium. This value is significant since it is closely related to the growth kinetics of microalgae (Ji et al. 2014). Although the N/P ratio during cultivation shows a separate trend for each medium (Table 1 ), which follow the movement of the growth curve of $C$. vulgaris (Figure 3) in the same period. The optimal N/P ratio for algal growth is 6.8-10 (Wang et al. 2009).

\section{REMOVAL EFFICIENCY OF N AND P SUBSTANCE FROM ADDMW}

The concentration of orthophosphate (PO4-P) in the ADDMW medium generally shows the declining trend for 14 days cultivation (Figure 4). The initial [PO4-P] in the ADDMW medium was reported at $26.72 \pm 0.00 \mathrm{ppm}$, while the lowest [PO4-P] was obtained on the 12th day with the value of $14.44 \pm 3.02 \mathrm{ppm}$. Thus, the PO4-P removal efficiency from this study was calculated at $45.95 \%$, which is similar achieved by Choi et al. (2012) with a range between 44.80 and 48.76 . However, this value is still far below the results attained by other studies that can reach $62 \%$ up to $94 \%$ (Franchino et al. 2013; Rao et al. 2011; Wang et al. 2010, 2009).

Phosphate compounds themselves are needed by $C$. vulgaris in a small quantity only to synthesize phospholipids, ATP, and nucleic acids (Rao et al. 2011). Nevertheless, C. vulgaris was also able to absorb phosphate at high removal efficiency with several

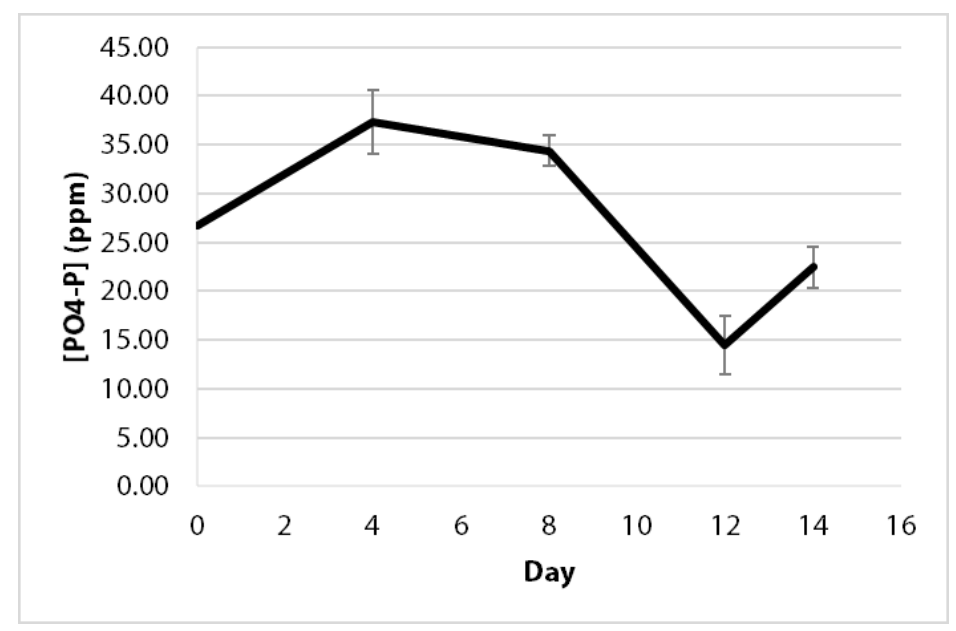

FIGURE 4. The orthophosphate (PO4-P) ion concentration in the ADDMW medium during the cultivation of $C$. vulgaris. Error bar shows the deviation standard with 3 replicates

mechanisms. One of the mechanisms is storing an excess amount of phosphate absorbed into the form of polyphosphate compounds (Powell et al. 2009). Another mechanism is precipitation, which can occur due to increased $\mathrm{pH}$ and dissolved oxygen concentrations
(Kumar et al. 2018). Conversely, a decrease in $\mathrm{pH}$ can lead to decreasing the concentration of dissolved phosphate in the medium (Sayadi et al. 2016).

The ammonium (NH4-N) concentration in the ADDMW medium showed a reduction after a significant

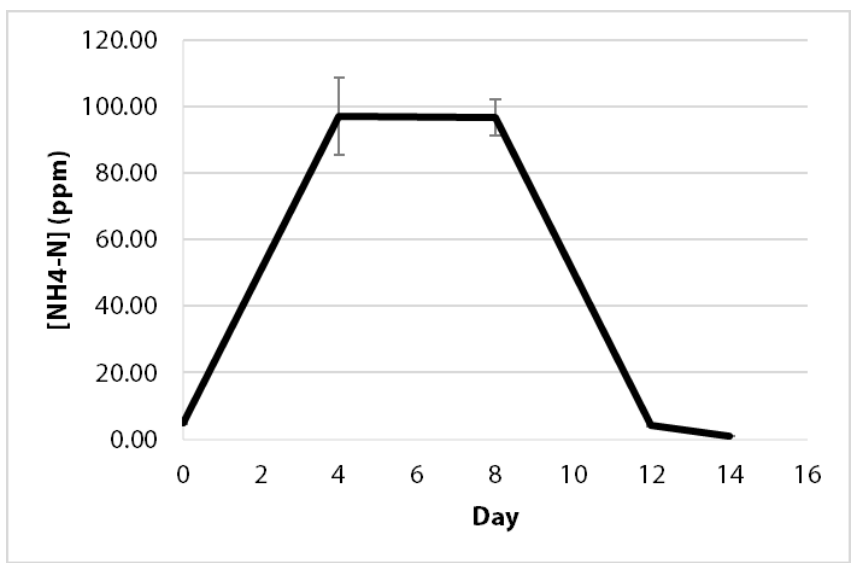

FIGURE 5. The ammonium (NH4-N) ion concentration on the ADDMW medium during the cultivation of $C$. vulgaris. Error bar shows the deviation standard with three replicates 
increase on the 4th day (Figure 5). The initial [NH4-N] was depicted at $4.84 \pm 0.39 \mathrm{ppm}$, while the lowest concentration reached at $1.05 \pm 0.00 \mathrm{ppm}$ on the 14 th day. The value of NH4-N removal efficiency obtained was $78.24 \%$, this is similar to the case reported where NH4-N removal reached $74.70-0.00 \%$ (Rao et al. 2011; Yang et al. 2015). Ammonium was used by $C$. vulgaris as the main source of nitrogen since it can be directly absorbed by the cell in one stage (6).

$$
\text { Glutamat }+\mathrm{NH}_{4}^{+}+\text {ATP } \rightarrow \text { Glutamin }+ \text { ADP }+ \text { Pi }
$$

Meanwhile, a significant increase of NH4-N at the 4th day occur because the ammonium ion undergoes a gasification process (Seyfabadi et al. 2011). This gasification is common because $\mathrm{NH}_{4}$ is a thermodynamically less stable form of nitrogen (Podder \& Majumder 2016). This phenomenon may increase the $\mathrm{pH}$ since the concentration of ammonium ions and hydroxide ions in the medium has an equilibrium relationship (7).

$$
\mathrm{NH}_{3}+\mathrm{H}_{2} \mathrm{O} \mathrm{NH} \mathrm{NH}^{+}+\mathrm{OH}^{-}
$$

The nitrate (NO3-N) concentration in the ADDMW medium showed an increase trend (Figure 6). Nitrate absorption efficiency values were obtained at $17.38 \%$. This value is lower than expected from the previous work by at least $29 \%$ (Wang et al. 2009). The low efficiency of nitrate absorption shows that $C$. vulgaris prioritizes the ammonium rather than nitrate as the nitrogen sources, especially when the ammonium concentration is still quite high. As stated by Goncalves et al. (2017), microalgae first reduce nitrate to nitrite using the nitrate reductase and reducing agent NADPH (8).

$$
\mathrm{NO}_{3}^{-}+2 \mathrm{H}^{+}+2 \mathrm{e}^{-} \rightarrow \mathrm{NO}_{2}^{-}+\mathrm{H}_{2} \mathrm{O}
$$

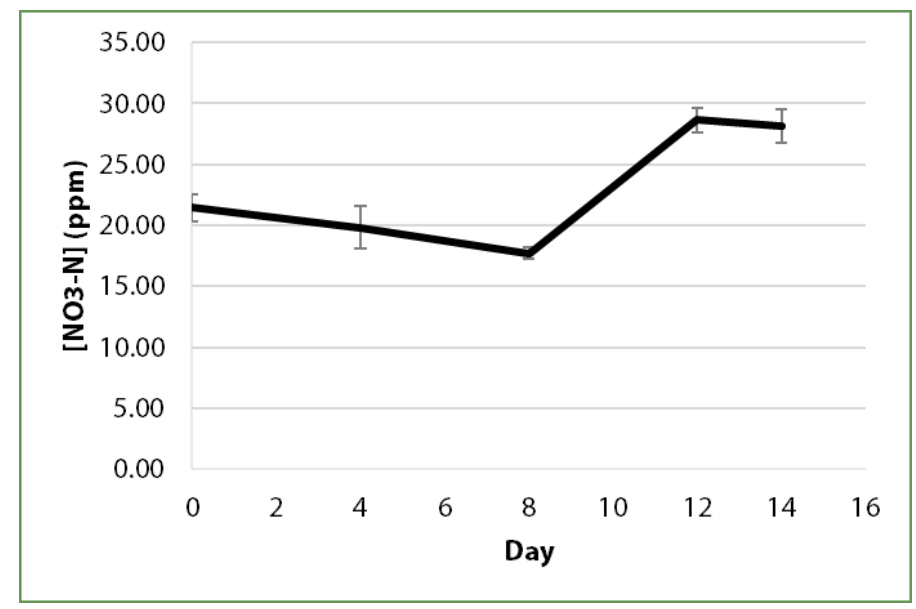

FIGURE 6. The nitrate (NO3-N) ion concentration on the ADDMW medium during the cultivation of $C$. vulgaris. Error bar shows the deviation standard with three replicates

Furthermore, nitrite is transformed into ammonium using the nitrite reductase with a ferredoxin as a reducing agent (9), and ammonium will then be absorbed directly by microalgae (6).

$$
\mathrm{NO}_{2}^{-}+8 \mathrm{H}^{+}+6 \mathrm{e}^{-} \rightarrow \mathrm{NH}_{4}^{+}+2 \mathrm{H}_{2} \mathrm{O}
$$

\section{CONCLUSION}

The cultivation of Chlorella vulgaris in the anaerobically digested dairy manure wastewater (ADDMW) medium was able to produce chlorophyll-a $34.62 \mu \mathrm{g} / \mathrm{mL}$ after being cultivated for 14 days and a protein content of
$35 \%$ after 28 days of cultivation. The addition of Walne to the ADDMW medium could not increase the protein and chlorophyll content of $C$. vulgaris. Moreover, $C$. vulgaris was also able to reduce levels of PO4-P, NH4-N, and NO3-N in the wastewater medium with a removal efficiency of $45.95,78.24$ and $17.38 \%$, respectively. The use of ADDMW for growth media and nutrient source of C. vulgaris was able to produce significant amount of biomass, chlorophyll and protein from the microalgae, and at the same time reduce the amount of phosphate, ammonium-nitrogen, and nitrate-nitrogen in organic wastewater from bioslurry. 


\section{ACKNOWLEDGEMENTS}

We thank The Institute for Research and Community Services of ITB (IRCS/LPPM-ITB) and the Ministry of Education and Culture (Indonesia) for funding this research through P3MI and PDUPT schemes for the year of 2018, 2019 and 2020.

\section{REFERENCES}

Amin, M., Chetpattananondh, P., Khan, M.N., Mushtaq, F. \& Sami, S.K. 2018. Extraction and quantification of chlorophyll from microalgae Chlorella sp. IOP Conference Series: Materials Science and Engineering 414(2018): 012025.

Chinnasamy, S., Ramakrishnan, B., Bhatnagar, A. \& Das, K.C. 2009. Biomass production potential of a wastewater alga Chlorella vulgaris ARC 1 under elevated levels of $\mathrm{CO}_{2}$ and temperature. International Journal of Molecular Sciences 10(2): 518-532.

Choi, H-J. \& Lee, S-M. 2012. Effects of microalgae on the removal of nutrients from wastewater: Various concentrations of Chlorella vulgaris. Environmental Engineering Research 17(51): 53-58.

Franchino, M., Comino, E., Bona, F. \& Riggio, V.A. 2013. Growth of three microalgae strains and nutrient removal from an agro-zootechnical digestate. Chemosphere 92(6): 738-744.

Goncalves, A.L., Pires, J.C.M. \& Simoes, M. 2017. A review on the use of microalgal consortia for wastewater treatment. Algal Research 24: 403-415.

Hena, S., Fatimah, S. \& Tabassum, S. 2015. Cultivation of algae consortium in a dairy farm wastewater for biodiesel production. Water Resources and Industry 10: 1-14.

Henchion, M., Hayes, M., Mullen, A., Fenelon, M. \& Tiwari, B. 2017. Future protein supply and demand: Strategies and factors influencing a sustainable equilibrium. Foods 6(7): 53.

Hu, B., Zhou, W., Min, M., Du, Z., Chen, P., Ma, X., Liu, Y., Lei, H., Shi, J. \& Ruan, R. 2013. Development of an effective acidogenically digested swine manure-based algal system for improved wastewater treatment and biofuel and feed production. Applied Energy 107: 255-263.

Ji, F., Liu, Y., Hao, R., Li, G., Zhou, Y. \& Dong, R. 2014. Biomass production and nutrients removal by a new microalgae strain Desmodesmus sp. in anaerobic digestion wastewater. Bioresource Technology 161: 200-207.

Jian-Ming, L., Cheng, L-H., Xu, X-H., Zhang, L. \& Chen, H-L. 2010. Enhanced lipid production of Chlorella vulgaris by adjustment of cultivation conditions. Bioresource Technology 101(17): 6797-6804.

Kumar, P.K., Krishna, S.V., Verma, K., Pooja, K., Bhagawan, D. \& Himabindu, V. 2018. Phycoremediation of sewage wastewater and industrial flue gases for biomass generation from microalgae. South African Journal of Chemical Engineering 25: 133-146.

Liang, Y., Kashdan, T., Sterner, C., Dombrowski, L., Petrick, I., Kroger, M. \& Hofer, R. 2015. Algal biorefineries. In Industrial Biorefineries \& White Biotechnology, edited by Ashok Pandey, Höfer, R., Mohammad Taherzadeh, K. Madhavan Nampoothiri \& Larroche, C. USA: Elsevier. pp. 35-90.

Podder, M.S. \& Majumder, C.B. 2016. Arsenic toxicity to Chlorella pyrenoidosa and its phycoremediation. Acta
Ecologia Sinica 36(4): 256-268.

Powell, N., Shilton, A., Chisti, Y. \& Pratt, S. 2009. Towards a luxury uptake process via microalgae - defining the polyphosphate dynamics. Water Research 43(17): 4207-4213.

Rao, P.H., Kumar, R.R., Raghavan, B.G., Subramanian, V.V. \& Sivasubramanian, V. 2011. Application of phycoremediation technology in the treatment of wastewater from a leather-processing chemical manufacturing facility. Water SA 37(1): 7-14.

Safafar, H., Norregaard, P.U., Ljubic, A., Moller, P., Holdt, S.L. \& Jacobsen, C. 2016. Enhancement of protein and pigment content in two Chlorella species cultivated on industrial process water. Journal of Marine Science and Engineering 4(4): 84-98

Sayadi, M.H., Ahmadpour, N., Capoorchali, M.F. \& Rezaei, M.R. 2016. Removal of nitrate and phosphate from aqueous solutions by microalgae: An experimental study. Global Journal of Environmental Science and Management 2(3): 357-364.

Seyfabadi, J., Ramenzapour, Z. \& Khoeyl, Z.A. 2011. Protein, fatty acid, and pigment content of Chlorella vulgaris under different light regimes. Journal of Applied Phycology 23: 721-726.

Simon, D. \& Hellineell, S. 1998. Extraction and quantification of chlorophyll-a from freshwater green algae. Water Research 32(7): 2220-2223.

Taufikurahman, T. \& Istiqomah, I.N. 2019. Phycoremediation of anaerobic digested dairy manure wastewater using microalgae Chlorella vulgaris. IOP Conference Series: Earth Environmental Science 299: 012013.

Wang, L., Li, Y., Chen, P., Min, M., Chen, Y., Zhu, J. \& Ruan, R.R. 2010. Anaerobic digested dairy manure as a nutrient supplement for cultivation of oil-rich green microalgae Chlorella sp. Bioresource Technology 101(8): 2623-2628.

Wang, L., Min, M., Li, Y., Chen, P., Chen, Y., Liu, Y., Wang, Y. \& Ruan, R. 2009. Cultivation of green algae Chlorella sp. in different wastewater from municipal wastewater treatment plant. Applied Biochemistry and Biotechnology 162(4): 1174-1186.

Yang, L., Tan, X., Li, D., Chu, H., Zhou, X., Zhang, Y. \& Yu, H. 2015. Nutrients removal and lipids production by Chlorella pyrenoidosa cultivation using anaerobic digested starch wastewater and alcohol wastewater. Bioresource Technology 181: 54-61.

Zheng, H., Yin, J., Gao, Z., Huang, H., Ji, X. \& Dou, C. 2011. Disruption of Chlorella vulgaris cells for the release of biodiesel-producing lipids: A comparison of grinding, ultrasonication, bead milling, enzymatic lysis, and microwaves. Applied Biochemistry and Biotechnology 164(7): 1215-1224.

Zhu, S., Qin, L., Feng, P., Shang, C., Wang, Z. \& Yuang, Z. 2018. Treatment of low $\mathrm{C} / \mathrm{N}$ ratio wastewater and biomass production using co-culture of Chlorella vulgaris and activated sludge in a batch photobioreactor. Bioresource Technology 274: 313-320.

Taufik Taufikurahman*, Muhammad Arief Ardiansyah \& Novi Tri Astutiningsih

School of Life Sciences and Technology

Institut Teknologi Bandung

40132 Bandung

Indonesia 
Eko Agus Suyono

Faculty of Biology

Universitas Gadjah Mada

55281 Yogyakarta

Indonesia
*Corresponding author; email: taufik@sith.itb.ac.id

Received: 15 January 2020

Accepted: 15 April 2020 